\title{
Some remarks on engine testing in dynamic states
}

\begin{abstract}
The paper presents a systematic approach towards the problems of dynamics of combustion engines. The notions of work processes of combustion engines and operating conditions as well as engine states of operation have been formally introduced. An axiomatic qualification of the engine operating process as static and dynamic has been proposed. The systematics of the engine operating states has been described. As an example of application of the proposed formalism the results of exhaust emission tests from the Detroit Diesel engine Series 50 have been shown (operating in the conditions of a HDDTT homologation test). The exhaust emissions were tested in the states: the whole test-increasing engine speed, decreasing engine speed and engine speed above idle. A high sensitivity of the average emission rate to types of discussed dynamic states has been observed.
\end{abstract}

Keywords: combustion engines, dynamics, static states, dynamic states

\section{Uwagi do badań silników spalinowych w stanach dynamicznych}

\begin{abstract}
W pracy przedstawiono systematyczne podejście do problemów dynamiki silników spalinowych. Wprowadzono formalnie pojęcia procesów pracy silników spalinowych oraz warunków pracy i stanów silników spalinowych. Zaproponowano aksjomatyczne kwalifikowanie procesów pracy silników jako statycznych i dynamicznych. Opisano systematykę stanów pracy silników spalinowych. Jako przykład zastosowania zaproponowanego formalizmu przedstawiono wyniki badań emisji zanieczyszczeń z silnika Detroit Diesel Series 50, pracujacego w warunkach homologacyjnego testu dynamicznego HDDTT. Badano emisję zanieczyszczeń w stanach: całego testu, zwiększania się prędkości obrotowej, zmniejszania się prędkości obrotowej oraz prędkości obrotowej większej od prędkości obrotowej biegu jałowego. Stwierdzono duża wrażliwość średnich wartości natężenia emisji na rodzaj rozpatrywanych stanów dynamicznych.
\end{abstract}

Słowa kluczowe: silniki spalinowe, dynamika, stany statyczne, stany dynamiczne

\section{Introduction}

For many years combustion engines have been tested in static states. The tests in dynamic states have been related to very specific conditions such as opacity tests at free acceleration. The fact that the engine properties are heavily dependent on the occurrence of dynamic states pushed the engineers to consider tests that are different than those commonly used in static states. A classic example of such tests is the exhaust emission tests in traffic conditions or dynamic tests on the engine test bed. These are tests that show the engine properties in dynamic states and the obtained values are averaged for the conditions of the whole test. There is virtually no tradition of more detailed investigations in these dynamic states. In general, the tests on engines in dynamic states are related either to the free acceleration or tests of the courses of certain values that determine the engine state. Only in few selected cases there are publications that contain more detailed results $[1,4-11,13]$.

A lack of well-established tradition of engine testing in dynamic states results in that the combustion engines specialists have a relatively weak formal knowledge on the process dynamics. Hence, very often, inappropriate nomenclature is used from the field of process dynamics, a classic example of which may be in the Polish language the wrong usage of the term 'stationary' rather than 'static'. This paper is an attempt to put order to things related to the testing of engines in dynamic states. To this end, this is only introductory information and the presentation of practical applications is limited to certain selected cases.

\section{Wstęp}

Przez wiele lat silniki spalinowe były badane przede wszystkim w stanach statycznych. Badania w stanach dynamicznych dotyczyły zazwyczaj bardzo szczegółowych warunków, np. badanie zadymienia spalin przy swobodnym przyspieszaniu. Świadomość faktu, że właściwości silników spalinowych są silnie zależne od występowania stanów dynamicznych skłania do coraz bardziej szczegółowego rozpatrywania badań odbiegających od powszechnie stosowanych standardów w stanach statycznych. Klasycznym przykładem takich badań są badania emisji zanieczyszczeń w warunkach testów jezdnych oraz w dynamicznych testach na hamowni silnikowej. Są to badania, które umożliwiają poznanie właściwości silników w stanach dynamicznych, przy czym właściwości te są uśrednione dla warunków całego testu. Tradycji bardziej wnikliwych badań w szczegółowo opisanych stanach dynamicznych w zasadzie nie ma. Ogólnie badania silników w stanach dynamicznych dotyczą zazwyczaj albo swobodnego przyspieszenia, albo testów o przebiegach wielkości, determinujących stan pracy silnika. Tylko w nielicznych wypadkach pojawiają się publikacje, zawierające bardziej szczegółowe wyniki $[1,4-11,13]$.

Brak dostatecznie ugruntowanej tradycji badania silników spalinowych w stanach dynamicznych powoduje, że w środowisku specjalistów silników spalinowych jest stosunkowo słaba strona formalna wiedzy o dynamice procesów. W związku z tym często stosowane są nawet niewłaściwie terminy z obszaru dynamiki procesów, czego klasycznym 


\section{Introductory information to the dynamics of combustion engines}

The operation of an engine is described by the engine operating conditions and engine states.

By the term of the process of physical quantity we understand the function of this quantity in the domain of time or a monotonic quantity in time [3, 7, 12] such as crankshaft angle or road covered by a vehicle while maintaining the conditions of non-negativeness of speed.

The quantities describing the engine operation treated as a function of time are processes of work of the combustion engine.

The combustion engine processes can be classified based on their frequency related properties such as [7]:

- Processes related to the individual cycles of the engine operation and quick changing processes as opposed to the processes related to typical engine use,

- Processes related to typical use of engines,

- Processes related to the engine wear and tear (tribologically) and slow changing processes as opposed to the processes related to typical engine use.

It is purposeful to introduce the term of characteristic frequencies of the analyzed processes. It is a frequency range for which the amplitudes of the frequency of the process representation have significant values [7]. In the case of quantitative evaluation it is necessary to determine the qualification criteria of the characteristic frequencies, yet we can use this term intuitively.

Quick changing processes are processes that are related to the engine cycle and condition the occurrence of this cycle, for example wave processes in the air flow in the intake manifold, fuel evaporation and diffusion processes, the processes of pre-flame fuel oxidation and combustion. In this group we can also include processes that are not always related to the cyclicity of the engine operation though most frequently generated by this cyclicity - vibrations of engine components. These processes can have their characteristic frequencies much higher than the processes directly related to the cycle of engine operation. In the individual cycles of engine operation the quick changing processes are decisive for the processes of formation and emission of exhaust components $[1,4,7]$. The characteristic frequencies of these processes must be at least one order of magnitude greater than the frequencies of the cycle of engine operation as they occur in a time that corresponds to the parts of individual cycles e.g. in a quick growth of pressure of the working medium in the cylinder during the combustion process. These are, thus, frequencies that are higher than several hertz.

Another group of processes is related to the operational type of forcing influencing the engine. The basic types of forcing are the processes of engine control and loads from the side of the power takeoff. The reaction of the vehicle is its speed, the reaction of the machine - faster operation, engine - engine speed.

By the term of engine control we understand the action of the operator on the engine, hence processes resulting from a displacement of the acceleration pedal: in the case of gasoline przykładem jest stosowanie nieumiejętnie przyswojonego z języków obcych terminu ,stacjonarny”, zamiast właściwego ,statyczny”. Niniejsza praca stanowi przyczynek do uporządkowania spraw, związanych z badaniami silników spalinowych w stanach dynamicznych. $Z$ tego powodu są to informacje wprowadzające, a ilustracja praktycznych zastosowań jest ograniczona do pewnych wybranych szczególnych przypadków.

\section{Wiadomości wprowadzające do dynamiki silników spalinowych}

Pracę silnika opisują warunki pracy oraz stan pracy. Pod pojęciem procesu wielkości fizycznej rozumie się funkcję tej wielkości w dziedzinie czasu lub wielkości monotonicznej względem czasu [3, 7, 12], np. kąta obrotu wału korbowego lub drogi przebywanej przez samochód przy zachowaniu warunku nieujemności prędkości.

Wielkości opisujące pracę silnika, traktowane jako funkcje czasu, są procesami pracy silnika spalinowego.

Procesy pracy silnika spalinowego można sklasyfikować na podstawie ich właściwości częstotliwościowych jako [7]:

- procesy związane z poszczególnymi cyklami pracy silnika oraz szybkozmienne w stosunku do procesów związanych z typowym użytkowaniem silników,

- procesy związane z typowym użytkowaniem silników,

- procesy związane z eksploatacyjnym zużywaniem się silników (trybologiczne) oraz wolnozmienne w stosunku do procesów związanych z typowym użytkowaniem silników.

Celowe jest wprowadzenie pojęcia częstotliwości charakterystycznych rozpatrywanych procesów. Jest to zakres wartości częstotliwości, dla których amplitudy częstotliwościowej reprezentacji procesu mają znaczące wartości [7]. W wypadku ilościowej oceny konieczne jest określenie kryteriów kwalifikowania częstotliwości charakterystycznych, można jednak używać tego pojęcia w sposób intuicyjny.

Procesy szybkozmienne są to procesy dotyczące obiegu silnika oraz warunkujące zachodzenie tego obiegu, np. procesy falowe w przepływie powietrza przez układ dolotowy, procesy parowania paliwa i dyfuzji par paliwa, procesy przedpłomiennego utleniania oraz spalania paliwa. Do grupy tej zaliczyć można również procesy nie zawsze całkowicie związane z cyklicznością pracy silnika, choć najczęściej generowane przez nią, np. drgania elementów silnika. Procesy te mogą mieć częstotliwości charakterystyczne znacznie większe niż procesy bezpośrednio związane z cyklami pracy silnika. W pojedynczych cyklach pracy silnika procesy szybkozmienne mają decydujące znaczenie dla procesów powstawania i emisji składników spalin [1, 4, 7]. Częstotliwości charakterystyczne tych procesów muszą być co najmniej o rząd wielkości większe od częstotliwości cykli pracy silnika, jako że zachodzą one w czasie odpowiadającym częściom pojedynczych cykli, np. w czasie szybkiego wzrostu ciśnienia czynnika roboczego w cylindrze w procesie spalania. Są to zatem częstotliwości większe od kilkudziesięciu herców. 
engine it results in an opening of the throttle valve and in the case of a diesel engine - displacement of the element that controls the fuel dose. The load for an engine is the moment of resistance that comes from the driven device. The dynamic properties of the engine control process in the conditions of real operation are determined by the factors related to the design of the control system and the individual features of the operator: physiological, volitional and praxeological. The research on the engine control processes indicates that the shortest time of depressing of the acceleration pedal is longer than $0.1 \mathrm{~s}$ [7]. This means that the characteristic frequencies of this process are certainly lower than $10 \mathrm{~Hz}$. At the same time the longest acceleration times do not exceed several seconds. We can thus assume that the bottom boundary frequency of the processes that characterize the tractvie operation is higher than $0.01 \mathrm{~Hz}$.

The dynamic properties of the moment that loads the engine are mostly related to the dynamic properties of the vehicle motion or machine operation and these depend on the engine control by the operator as well as on the motion or work resistance. Because in the dynamic system 'engine control'- 'power takeoff'- 'quickness of operation' inertia elements play an important role we can judge that the characteristic frequencies of the process of the moment of resistance are lower than those of the process of engine control. One should, however include additional factors that generate the forcing of the moment of resistance of high frequency- most of all the processes of vibration in the drivetrain. The amplitudes of these processes are much lower as opposed to the amplitude of the basic process. This results mainly from the existence of damping components in the drivetrain. We can thus assume that the characteristic frequencies of the processes related to the typical engine use are lower than $10 \mathrm{~Hz}$.

The slow changing processes as opposed to the processes related to the use of engines have an entirely different dynamic character than those considered so far. To the category of slow changing processes we can include the thermal processes that characterize the thermal state of the engine. These processes have the time constants of several minutes at the most and several seconds at least [7].

The thermal state of an engine can be determined by the set of temperatures of the engine parts such as: coolant or engine oil. As a parameter of the thermal state of the engine we can assume the representative temperature out of the elements of the engine e.g. the temperature of coolant or engine oil [7].

Even more slow changing processes than the thermal ones in the engine are processes that describe the atmospheric conditions, and even more so the tribological processes that are related to the engine wear.

The state of a combustion engine operation is described with a set of quantities that characterize this operation in the conditions of typical engine use such as those quantities that characterize:

- The energy related properties understood as a potential to perform a work such as power output, torque, engine
Druga grupa procesów jest związana z eksploatacyjnymi wymuszeniami oddziałującymi na silnik. Podstawowymi wymuszeniami są procesy sterowania silnika i obciążenia ze strony odbiornika mocy. Reakcją pojazdu jest prędkość jazdy, maszyny roboczej - szybkość pracy, a silnika - prędkość obrotowa.

Przez pojęcie sterowanie silnika rozumie się oddziaływanie operatora na silnik, a zatem procesy wywołane przemieszczaniem pedału lub manetki przyspieszania: w wypadku silnika o zapłonie iskrowym powoduje to przede wszystkim uchylanie przepustnicy, w wypadku silnika o zapłonie samoczynnym - przemieszczanie elementu sterującego dawkę paliwa. Obciążeniem dla silnika jest moment oporu, pochodzący od napędzanego urządzenia. Właściwości dynamiczne procesu sterowania silnika $\mathrm{w}$ warunkach rzeczywistego użytkowania są zdeterminowane czynnikami związanymi z konstrukcją układu sterowania oraz cechami operatora: fizjologicznymi, wolicjonalnymi oraz prakseologicznymi. Badania procesów sterowania silnika wskazują, że najkrótszy czas wciśnięcia pedału przyspieszania jest dłuższy od 0,1 s [7]. Oznacza to, że charakterystyczne częstotliwości tego procesu są na pewno mniejsze od $10 \mathrm{~Hz}$. Jednocześnie najdłuższe czasy przyspieszania nie przekraczają kilkudziesięciu sekund. Można zatem przyjąć, że dolna graniczna częstotliwość procesów charakteryzujących eksploatację trakcyjną jest większa od $0,01 \mathrm{~Hz}$.

Właściwości dynamiczne momentu obciążającego silnik związane są przede wszystkim z właściwościami dynamicznymi ruchu pojazdu lub pracy maszyny, a te z kolei zależą od sterowania silnika przez operatora oraz od oporów ruchu lub pracy. Ponieważ w układzie dynamicznym "sterowanie silnika - odbiornik mocy - prędkość działania" istotną rolę odgrywają elementy inercyjne, można wnioskować, że częstotliwości charakterystyczne procesu momentu oporu są mniejsze niż procesu sterowania silnika. Należy jednak uwzględnić dodatkowe czynniki, generujące wymuszenie momentu oporu o wysokiej częstotliwości, przede wszystkim procesy drgań w układzie napędowym. Amplitudy tych procesów są jednak w stosunku do amplitudy procesu podstawowego znacznie mniejsze, wynika to przede wszyst$\operatorname{kim} \mathrm{z}$ istnienia $\mathrm{w}$ układzie przeniesienia napędu elementów tłumiących. Można w związku z tym przyjąć, że częstotliwości charakterystyczne procesów związanych z typowym użytkowaniem silnika są mniejsze od $10 \mathrm{~Hz}$.

Procesy wolnozmienne w stosunku do procesów związanych z użytkowaniem silników mają zupełnie odmienny charakter dynamiczny od rozpatrywanych do tej pory. Do kategorii procesów wolnozmiennych można zaliczyć procesy cieplne charakteryzujące stan cieplny silnika. Procesy te mają stałe czasowe rzędu kilku lub kilkunastu minut, a co najmniej kilkudziesięciu sekund [7].

Stan cieplny silnika może być określony zbiorem temperatur części silnika i jego czynników, takich jak: ciecz chłodząca i olej silnikowy. Jako parametr stanu cieplnego silnika można przyjąć temperaturę spośród elementów stanu cieplnego, uznaną za reprezentatywną, np. temperaturę cieczy chłodzącej lub oleju silnikowego [7]. 
speed, working medium pressure in the cylinder, means indicated pressure, mean effective pressure etc.,

- The controllable processes that take place in the engine such as: engine control by the operator, ignition timing or injection timing, charging pressure, intake air temperature, working medium temperature, engine thermal state, exhaust recirculation coefficient, mixture composition and sometimes compression ratio etc.,

- Economic properties in terms of fuel consumption such as: thermal efficiency, mechanical efficiency, general efficiency, fuel flow rate, specific fuel consumption etc.,

- Properties that characterize the processes accompanying the engine operation - ecological properties such as exhaust emissions (concentrations of exhaust components, emission rate, unit emission of the components and in vehicle applications - road emissions) as well as noise emission e.g. noise intensity and its level or noise acoustic pressure and its level or possibly engine acoustic power and its level.

The engine operating conditions are determined by:

- The ambient conditions that influence the vehicle or machine motion resistance and the atmospheric conditions,

- The control of the engine by the operator,

- The moment of resistance depending on the character of work performed by the engine or the machine.

Let the engine conditions be determined by set of physical quantities $\mathbf{W}$.

$$
\mathbf{W}=\left\{\mathrm{W}_{1}, \mathrm{~W}_{2}, \ldots \mathrm{W}_{\mathrm{W}}\right\}
$$

The engine operating state is described with set of physical quantities $\mathbf{S}$.

$$
\mathrm{S}=\left\{\mathrm{S}_{1}, \mathrm{~S}_{2}, \ldots \mathrm{S}_{\mathrm{iS}}\right\}
$$

The engine work is characterized by set $\mathbf{P}$ that is a sum of the sets of the engine conditions and engine operating states.

$$
\mathbf{P}=\mathbf{W} \cup \mathbf{S}=\left\{\mathrm{P}_{1}, \mathrm{P}_{2}, \ldots \mathrm{P}_{\mathrm{iP}}\right\}
$$

where: $\mathrm{iP}<=\mathrm{iW}+\mathrm{iS}$

Formally, the engine work is static if all the quantities that describe the engine work are independent of time t, i.e.

$$
\frac{\partial \mathrm{P}_{\mathrm{i}}(\mathrm{t})}{\partial \mathrm{t}}=0
$$

for $i=1, \ldots$, iP.

If for any of the quantities that describe the engine work this condition is not fulfilled the engine work is dynamic.

The above criterion of engine qualification into the static or dynamic category is of theoretical significance as it can refer only to the cases of analytic description of function $\mathrm{P}_{\mathrm{i}}(\mathrm{t})$. If function $\mathrm{P}_{\mathrm{i}}(\mathrm{t})$ is presented in the empirical form of signals, which is always the case in practice then fulfilling conditions (4) is dependent on the frequency properties of the analyzed signals. Hence, it is purposeful to limit the upper frequency range of the analyzed signals to an arbitrary value $f_{g}$. Hence, signals $P_{i}(t)$ are filtered with an ideal low-
Procesami jeszcze bardziej wolnozmiennymi niż cieplne są procesy opisujące warunki atmosferyczne, a tym bardziej procesy trybologiczne związane ze zużywaniem się silników.

Stan pracy silnika spalinowego jest opisany zbiorem wielkości, charakteryzujących tę pracę $\mathrm{w}$ warunkach typowego użytkowania silnika, a więc m.in. wielkościami charakteryzującymi:

- właściwości energetyczne ze względu na możliwość wykonania pracy, takie jak moc użyteczne, moment obrotowy, prędkość obrotowa, ciśnienie czynnika w cylindrze, średnie ciśnienie indykowane, średnie ciśnienie użyteczne itd.,

- procesy zachodzące w silniku podlegające sterowaniu, takie jak: sterowanie silnika przez operatora, dawka paliwa, kąt wyprzedzenia zapłonu lub kąt wyprzedzenia wtrysku, ciśnienie doładowania, temperatura powietrza napełniającego cylindry, temperatura czynnika w cylindrze, stan cieplny silnika, współczynnik recyrkulacji spalin, skład mieszanki palnej, niekiedy stopień sprężania itd.,

- właściwości ekonomiczne ze względu na zużycie paliwa, takie jak: sprawność cieplna, sprawność mechaniczna, sprawność ogólna, natężenie przepływu paliwa zużywanego przez silnik, jednostkowe zużycie paliwa itd.,

- właściwości charakteryzujące procesy towarzyszące pracy silnika, m.in. właściwości ekologiczne ze względu na emisję zanieczyszczeń (stężenia składników spalin, natężenia emisji zanieczyszczeń, emisje jednostkowe zanieczyszczeń, a w zastosowaniach samochodowych emisje drogowe zanieczyszczeń) oraz emisję hałasu, np. natężenie hałasu i jego poziom, czy ciśnienie akustyczne hałasu i jego poziom, ew. moc akustyczna silnika i jej poziom.

Warunki pracy silnika są zdeterminowane:

- warunkami otoczenia, mającymi wpływ na opory pracy pojazdu lub maszyny, oraz warunkami atmosferycznymi,

- sterowaniem silnika przez operatora,

- momentem oporu, zależnym od charakteru pracy wykonywanej przez pojazd lub maszynę.

Niech warunki pracy silnika będą określone zbiorem wielkości fizycznych $\mathbf{W}$ - równanie (1).

Stan pracy silnika jest opisany zbiorem wielkości fizycznych $\mathbf{S}$ - równanie (2).

Pracę silnika charakteryzuje zbiór P będący sumą zbiorów warunków pracy i stanu pracy silnika - równanie (3) gdzie: $\mathrm{iP}<=\mathrm{iW}+\mathrm{iS}$

Formalnie praca silnika ma charakter statyczny, jeśli wszystkie wielkości, opisujące pracę silnika, są niezależne od czasu $\mathrm{t}$ - równanie (4) dla $\mathrm{i}=1, \ldots, \mathrm{iP}$.

Jeśli dla którejkolwiek wielkości, opisującej pracę silnika, ten warunek nie jest spełniony, praca silnika ma charakter dynamiczny.

Powyższe kryterium kwalifikacji pracy silnika do kategorii statycznej lub dynamicznej ma znaczenie czysto teoretyczne, może się bowiem odnosić jedynie do przypad- 
pass filter of the flyback frequency $f_{g}$, thus of the amplitude - frequency characteristics:

$$
H(f)=\left\{\begin{array}{l}
1 \text { dla } f \leq f_{g} \\
0 \text { dla } f>f_{g}
\end{array}\right.
$$

The filtered signals are marked $\overline{\mathrm{P}}_{\mathrm{i}}(\mathrm{t})$. In relation to that, the criterion of qualification of engine operation as static or dynamic takes a form:

$$
\frac{\partial \overline{\mathrm{P}}_{\mathrm{i}}(\mathrm{t})}{\partial \mathrm{t}}=0
$$

for $\mathrm{i}=1, \ldots$, iP.

In real conditions it is purposeful to assume a lighter criterion of qualification of engine operation as static or dynamic. Let us assume a set of positive numbers $\varepsilon$.

$$
\varepsilon=\left\{_{1}, \varepsilon_{2}, \ldots \varepsilon_{\mathrm{iP}}\right\}
$$

If, for all signals that describe the engine operation, processed with the use of a low pass filter of the flyback frequency $f_{d}$, the conditions

$$
\frac{\partial \overline{\mathrm{P}}_{\mathrm{i}}(\mathrm{t})}{\partial \mathrm{t}}<\varepsilon_{\mathrm{i}}
$$

are fulfilled

for $i=1, \ldots, i P$, then the engine operation is static with the accuracy determined by set $\varepsilon$. In all other cases the engine operation is dynamic. The selection of the elements of set $\varepsilon$ is determined by the objectives set by the engineers before the research is initiated.

\section{Combustion engine work balance}

The balance of work of a combustion engine can be described with a differential equation

$$
\frac{\mathrm{d}}{\mathrm{dt}}[\mathrm{J}(\mathrm{t}) \cdot \omega(\mathrm{t})]=\mathrm{M}_{\mathrm{e}}(\mathrm{t})-\mathrm{M}_{\mathrm{o}}(\mathrm{t})
$$

where: $\mathrm{M}_{\mathrm{e}}-$ engine torque, $\mathrm{M}_{\mathrm{o}}$ - resistance torque, $\mathrm{J}-$ moment of inertia of the moving parts directed to the axis of the crankshaft, $\omega-$ angular velocity of the engine crankshaft.

The torque in dynamic states is described with the operator dependence of the courses of angular velocity $\omega(t)$ and engine control by operator $\mathrm{s}(\mathrm{t})^{1)}$.

$$
\mathrm{M}_{\mathrm{e}}=\mathbf{F}_{\mathbf{M}_{\mathrm{e}}}[\omega(\mathrm{t}) \mathrm{s}(\mathrm{t})]
$$

in the form of a functional whose analytical form is dependent on the courses of the angular velocity and engine control by the operator.

$$
\mathrm{M}_{\mathrm{e}}=\mathbf{F}_{\mathbf{M}_{\mathrm{e}}}[\omega(\mathrm{t}) \mathrm{s}(\mathrm{t})]=\int_{0}^{\mathrm{t}} \mathbf{f}_{\mathbf{M}_{\mathrm{e}}}[\omega(\tau), \mathrm{s}(\tau)] \cdot \mathrm{d} \tau
$$

\footnotetext{
1) The arguments of the general function (abstract, operator function) [2] are notated in brackets as opposed to arguments of elementary function notated in parentheses.
}

ków opisu analitycznego funkcji $\mathrm{P}_{\mathrm{i}}(\mathrm{t})$. Jeśli funkcje $\mathrm{P}_{\mathrm{i}}(\mathrm{t})$ są przedstawione $\mathrm{w}$ empirycznej postaci sygnałów, co ma zawsze miejsce w praktyce, to spełnienie warunków (4) jest zależne od właściwości częstotliwościowych analizowanych sygnałów. Jest celowe - w związku z tym - ograniczenie górnego zakresu częstotliwości analizowanych sygnałów do arbitralnie przyjętej wartości $\mathrm{f}_{\mathrm{g}}$. W związku $\mathrm{z}$ tym sygnały $\mathrm{P}_{\mathrm{i}}(\mathrm{t})$ są poddawane filtracji idealnym filtrem dolnoprzepustowym o częstotliwości zaporowej równej $\mathrm{f}_{\mathrm{g}}$, a zatem o charakterystyce amplitudowo-częstotliwościowej-(5).

Przefiltrowane sygnały są oznaczone jako $\overline{\mathrm{P}}_{\mathrm{i}}(\mathrm{t})$. W związku z tym kryterium kwalifikacji pracy silnika do kategorii statycznej lub dynamicznej przyjmuje postać (6)

dla $\mathrm{i}=1, \ldots, \mathrm{iP}$.

W rzeczywistych warunkach jest celowe przyjęcie łagodniejszego kryterium kwalifikacji pracy silnika do kategorii statycznej lub dynamicznej. Przyjmijmy zbiór liczb dodatnich $\varepsilon$ - równanie (7).

Jeśli dla wszystkich sygnałów, opisujących pracę silnika, przetworzonych z zastosowaniem filtru dolnoprzepustowego o częstotliwości zaporowej $\mathrm{f}_{\mathrm{d}}$, spełnione są warunki (8) dla $\mathrm{i}=1, \ldots$, iP, to praca silnika ma charakter statyczny $z$ dokładnością określoną zbiorem $\varepsilon$. We wszystkich innych wypadkach praca silnika ma charakter dynamiczny. Dobór wartości elementów zbioru $\varepsilon$ jest zdeterminowany celami stawianymi przed przewidywanymi badaniami.

\section{Bilans pracy silnika spalinowego}

Bilans pracy silnika spalinowego można opisać równaniem różniczkowym (9)

gdzie: $\mathrm{M}_{\mathrm{e}}-$ moment obrotowy silnika, $\mathrm{M}_{\mathrm{o}}-$ moment obrotowy oporu, $\mathrm{J}$ - moment bezwładności ruchomych części silnika sprowadzony na oś wału korbowego, $\omega$ - prędkość kątowa wału korbowego silnika.

Moment obrotowy w warunkach dynamicznych jest opisany zależnością operatorową przebiegów prędkości kątowej $\omega(\mathrm{t})$ i sterowania silnika przez operatora $\mathrm{s}(\mathrm{t})^{1)}$ - równanie (10) w postaci funkcjonału, którego postać analityczna jest zależna od przebiegów prędkości kątowej i sterowania silnika przez operatora - równanie (11).

Zatem bilans pracy silnika spalinowego jest opisany w postaci równania (12) czyli w postaci (13).

Analizowany model silnika jest nieliniowym modelem różniczkowo-całkowym opisany równaniem (14).

Różniczkując, otrzymuje się równanie (15).

$\mathrm{W}$ chwili $\mathrm{t}=0$, odpowiadającej początkowi pracy silnika spalinowego, $\omega(0)=\omega_{0}$.

Wymuszeniami są dla $t \in[0 ; T]: M_{o}(t), s(t)$. Dana jest dla założonych warunków pracy zależność $\mathrm{J}(\mathrm{t})$ dla $\mathrm{t} \in[0 ; \mathrm{T}]$ . W wyniku analizy modelu matematycznego (15) należy wyznaczyć zależność prędkości kątowej od czasu $\omega(\mathrm{t})$ dla $t \in[0 ; T]^{2}$.

\footnotetext{
1) Argumenty funkcji uogólnionej (abstrakcyjnej, operatora) [2] są zapisywane w nawiasach kwadratowych w odróżnieniu od argumentów funkcji elementarnej zapisywanych w nawiasach okrągłych.

${ }^{2)} \mathrm{W}$ modelu pracy silnika spalinowego można oczywiście zastąpić prędkość kątową $\omega$ prędkością obrotową $n$.
} 
Hence, the balance of the combustion engine operation is described as follows

$$
\frac{\mathrm{d}}{\mathrm{dt}}[\mathrm{J}(\mathrm{t}) \cdot \omega(\mathrm{t})]=\mathbf{F}_{\mathbf{M}_{\mathrm{c}}}[\omega(\mathrm{t}) \mathrm{s}(\mathrm{t})]-\mathrm{M}_{\mathrm{o}}(\mathrm{t})
$$

i.e.:

$$
J(t) \cdot \frac{d \omega(t)}{d t}+\omega(t) \cdot \frac{d J(t)}{d t}=F_{M_{c}}[\omega(t) s(t)]-M_{o}(t)
$$

The analyzed model of the engine is a non-linear differential-integral model:

$$
J(t) \cdot \frac{d \omega(t)}{d t}+\omega(t) \cdot \frac{d J(t)}{d t}=\int_{0}^{t} \mathbf{f}_{M_{e}}[\omega(\tau), s(\tau)] \cdot d \tau-M_{o}(t)
$$

When applying a differential we obtain:

$$
\begin{gathered}
J(t) \cdot \frac{\mathrm{d}^{2} \omega(\mathrm{t})}{\mathrm{dt}^{2}}+2 \cdot \frac{\mathrm{dJ}(\mathrm{t})}{\mathrm{dt}} \cdot \frac{\mathrm{d} \omega(\mathrm{t})}{\mathrm{dt}}+\omega(\mathrm{t}) \cdot \frac{\mathrm{dJ} \mathrm{J}^{2}(\mathrm{t})}{\mathrm{dt}^{2}}- \\
\mathbf{f}_{\mathbf{M}_{\mathrm{e}}}[\omega(\tau), \mathrm{s}(\tau)]+\frac{\mathrm{dM_{o } ( t )}}{\mathrm{dt}}=0
\end{gathered}
$$

In moment $t=0$, that corresponds to the start of the engine operation, $\omega(0)=\omega_{0}$.

The forcings for $t \in[0 ; T]$ are: $M_{0}(t), s(t)$. For the engine conditions the dependence $J(t)$ is given for $t \in[0 ; T]$. As a result of the analysis of the mathematical model (15) we need to determine the dependence of the angular velocity on time $\omega(\mathrm{t})$ for $\mathrm{t} \in[0 ; \mathrm{T}]^{2)}$.

Figure 1 presents the schematics of the dependence of the engine state on the forcings in the mathematical model of the engine operation.

The most important problem in the investigation of the engine operation model is the unknown characteristics $\mathbf{f}_{\mathbf{M}_{\mathrm{e}}}[(\tau) \mathrm{s}(\tau)]$ that can be interpreted as a dynamic characteristics of the torque depending on the angular velocity and engine control by the operator. As we know the engine torque in general in dynamic states is dependent on the angular velocity and engine control, hence, its value on moment $t$ depends on the courses of the angular velocity and engine control in time $t \in[0 ; T]$. Hence, in general for each combination of the possibly realizable courses of angular velocity and engine control there are different values of the engine torque. The possibility of investigating the engine operation mathematical model is complicated by the fact that the sought course of the angular velocity is an argument in the operator characteristics of the engine torque and the torque has an obvious impact on the angular velocity. Hence, it is impossible to determine the characteristics of the torque in dynamic states. As a consequence - in order to enable research of the combustion engine properties in dynamic states it is necessary to limit the generality of the given task by imposing additional constraints on the investigated system. Most frequently these are the constraints related to the generality of the forcings - the processes of the moment of resistance and

\footnotetext{
${ }^{2)}$ In the model of engine operation we can replace angular velocity $\omega$ with engine speed $n$.
}

Na rysunku 1 przedstawiono schemat zależności stanu pracy silnika spalinowego od wymuszeń w modelu matematycznym pracy silnika.

$s(t)$

$\mathrm{M}_{\mathrm{o}}(\mathrm{t})$

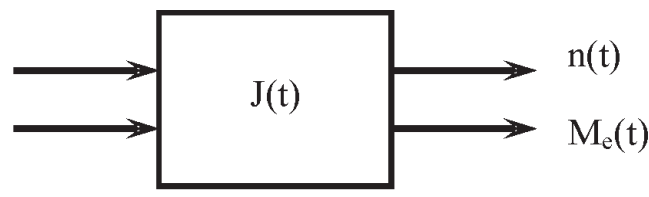

Fig. 1. Schematics of the dependence of the engine operating states on the forcings in the mathematical engine operation model

Rys. 1. Schemat zależności stanu pracy silnika spalinowego od wymuszeń $w$ modelu matematycznym pracy silnika

Najważniejszym problemem badania modelu pracy silnika spalinowego jest nieznana charakterystyka $\mathbf{f}_{\mathbf{M}_{e}}[\omega(\tau), s(\tau)]$, którą można interpretować jako charakterystykę dynamiczną momentu obrotowego silnika w zależności od prędkości kątowej i sterowania silnika przez operatora. Jak wiadomo, moment obrotowy silnika spalinowego jest w ogólności w warunkach dynamicznych zależny w sposób operatorowy od prędkości kątowej i sterowania silnika, a zatem jego wartość w chwili $t$ jest zależna od przebiegów prędkości kątowej i sterowania silnika w czasie $t \in[0 ; T]$. W związku z tym w ogólności dla każdej kombinacji możliwych do zrealizowania przebiegów prędkości kątowej i sterowania silnika są różne wartości momentu obrotowego silnika. Możliwość badań modelu matematycznego pracy silnika spalinowego komplikuje znacznie fakt, że poszukiwany przebieg prędkości kątowej jest uwikłany jako argument w operatorowej charakterystyce momentu obrotowego silnika, a moment obrotowy ma oczywisty wpływ na prędkość kątową. W związku z tym nie jest możliwe w ogólności wyznaczenie charakterystyki momentu obrotowego $\mathrm{w}$ warunkach dynamicznych. W konsekwencji - w celu umożliwienia badania właściwości silników spalinowych w warunkach dynamicznych - jest konieczne ograniczenie ogólności postawionego zadania przez nałożenie na badany układ dodatkowych więzów. Najczęściej są to ograniczenia ogólności wymuszeń - procesów momentu oporu i sterowania silnika w postaci przyjęcia pewnych klas tych procesów lub - przede wszystkim - przyjęcia ich konkretnych realizacji, a zatem funkcji przyczynowych. Taką rolę odgrywają testy dynamiczne do badania właściwości silników spalinowych. W testach dynamicznych przyjmuje się - co prawda - nie przebiegi momentu oporu i sterowania silnika, tylko momentu obrotowego silnika i jego prędkości obrotowej, tak dobierając sterowanie silnika, aby przy przyjętych parametrach bezwładności układu osiągnąć wymagane przebiegi momentu obrotowego i prędkości obrotowej - rysunek 2 .

\section{Zasady badania silników spalinowych w dynamicznych stanach pracy}

Oczywiście nie jest możliwe w ogólności badanie właściwości dynamicznych obiektów, których modele matematyczne, uznane za dostatecznie zgodne z przedmiotem badania, są modelami nieliniowymi [3]. Układy takie, jak wiadomo, nie mają właściwości niezależnych od stanu, w 
engine control taken in the form of assuming certain classes of these processes or assuming their realizations - causative functions. Such a purpose is served by the dynamic tests that investigate the engine properties. In dynamic tests not the courses of the moment of resistance and engine control are assumed but engine torque and its speed so that at such assumed parameters of inertia the required courses of engine torque and speed are obtained - Fig. 2.

\section{The principles of combustion engine testing in dynamic states}

It is obviously impossible to test the dynamic properties of an object whose mathematical models (recognized as sufficiently compliant with the original) are non-linear [3]. Such systems, as is known, do not have properties independent of the state in which they are as opposed to systems that can be described with linear models with a sufficient compliance. Obviously, the combustion engines even when only balancing their operation, have to be described with non-linear models. Hence, it is impossible to investigate the dynamic properties of the combustion engines, only particular cases can be investigated.

One of the most frequently applied methods of engine testing in dynamic states is as said earlier, determining the averaged value of the tested quantities for an engine state determined by the assumed courses of the quantities described with research tests.

Out of a variety of possibilities to simplify the description of the dynamic conditions and engine states there is also a possibility of defining of the elementary conditions and engine states depending on their values and change intensity, thus, on the derivatives in time.

According to the analyzed causes and effects of the dynamic operation of the engines we can propose a classification of conditions and engine states. The causes of the engine states, if a constant thermal state is assumed, are the processes of engine control by the operator and the moment of resistance and the effect is the process of engine speed that depends on the engine torque. The elementary description of the engine can be defined with values and derivatives in time for these values: engine control by the operator, moment of resistance and engine speed. The engine operation quantities that fulfill the conditions:

$$
\begin{gathered}
\mathrm{s} \in\left[\mathrm{s}_{\mathrm{i}}-\frac{\varepsilon_{\mathrm{s}}}{2} ; \mathrm{s}_{\mathrm{i}}+\frac{\varepsilon_{\mathrm{s}}}{2}\right] \\
\mathrm{M}_{\mathrm{o}} \in\left[\mathrm{M}_{\mathrm{oi}}-\frac{\varepsilon_{\mathrm{Mo}}}{2} ; \mathrm{M}_{\mathrm{oi}}+\frac{\varepsilon_{\mathrm{Mo}}}{2}\right] \\
\mathrm{n} \in\left[\mathrm{n}_{\mathrm{i}}-\frac{\varepsilon_{\mathrm{n}}}{2} ; \mathrm{n}_{\mathrm{i}}+\frac{\varepsilon_{\mathrm{n}}}{2}\right]
\end{gathered}
$$

form set $\mathrm{A}$

The derivatives of the engine operation quantities fulfill the conditions:

$$
\left.\frac{\mathrm{ds}}{\mathrm{dt}}\right|_{\mathrm{s}, \mathrm{M}_{\mathrm{o}}, \mathrm{n} \in \mathrm{A}} \in\left[\delta_{\mathrm{s}}-\frac{\varepsilon_{\delta \mathrm{s}}}{2} ; \delta_{\mathrm{s}}+\frac{\varepsilon_{\delta \mathrm{s}}}{2}\right]
$$

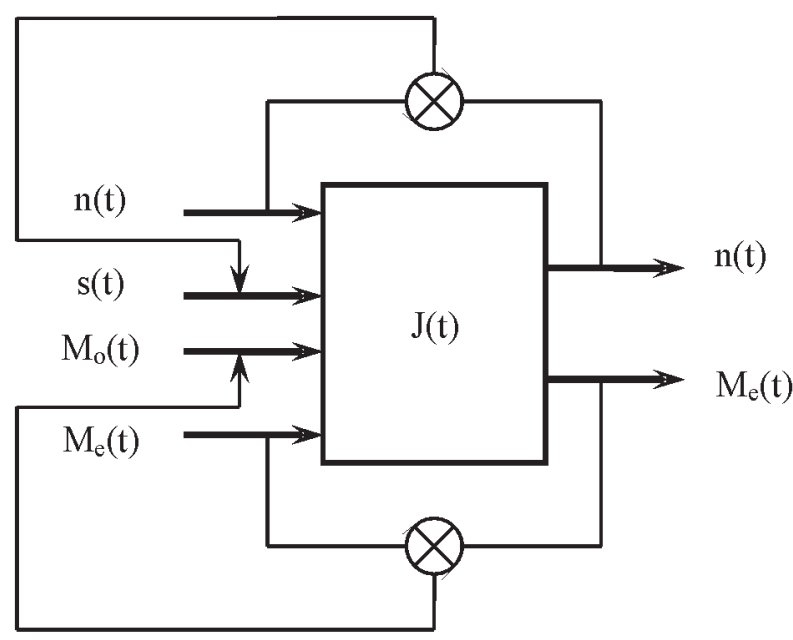

Fig. 2. Schematics of the engine control and moment of resistance in order to receive the engine torque and speed

$$
\begin{aligned}
& \text { Rys. 2. Schemat regulacji sterowania silnika i momentu oporu w celu } \\
& \text { odtworzenia momentu obrotowego i prędkości obrotowej }
\end{aligned}
$$

jakim się znajdują, w odróżnieniu od układów, które mogą być opisywane $\mathrm{z}$ dostatecznie dobrą zgodnością modelami liniowymi. Oczywiście silniki spalinowe, nawet tylko w wypadku bilansowania ich pracy, muszą być opisywane modelami nieliniowymi. W związku z tym nie ma możliwości w ogólności badania dynamicznych właściwości silników spalinowych, istnieje możliwość badania jedynie szczególnych przypadków.

Jedną z najczęściej stosowanych możliwości badania silników spalinowych, znajdujących się w stanie dynamicznym, jest - wspomniane wcześniej - wyznaczanie uśrednionych wartości badanych wielkości dla stanu silnika, zdeterminowanego przyjętymi przebiegami wielkości, opisanymi konkretnymi testami badawczymi.

Spośród różnych możliwości uproszczenia opisu dynamicznych warunków i stanów pracy silnika spalinowego istnieje również możliwość zdefiniowania elementarnych warunków i stanów pracy silnika w zależności od ich wartości oraz od ich intensywności zmian, a zatem od pochodnych względem czasu.

Zgodnie $\mathrm{z}$ analizowanymi przyczynami i skutkami dynamicznej pracy silników spalinowych można zaproponować klasyfikację warunków i stanu pracy silnika. Przyczynami stanu silnika przy założeniu stałego stanu cieplnego są procesy sterowania silnika przez operatora $i$ momentu oporu, a skutkiem proces prędkości obrotowej, zależny od momentu obrotowego. Elementarny opis pracy silnika może być zdefiniowany wartościami oraz pochodnymi względem czasu dla tych wartości: sterowania silnika przez operatora, momentu oporu i prędkości obrotowej. Wielkości pracy silnika spełniające warunki (16) - (18) tworzą zbiór A.

Pochodne wielkości pracy silnika spełniają warunki (19) - (21).

Ze względu na definiowanie większości testów dynamicznych do badania silników spalinowych najczęściej rejestruje się moment obrotowy silnika, a nie moment oporu. 


$$
\begin{aligned}
\left.\frac{\mathrm{dM}}{\mathrm{dt}}\right|_{\mathrm{s}, \mathrm{M}_{\mathrm{o}}, \mathrm{n} \in \mathrm{A}} \in\left[\delta_{\mathrm{M}_{\mathrm{o}}}-\frac{\varepsilon_{\delta \mathrm{M}_{\mathrm{o}}}}{2} ; \delta_{\mathrm{M}_{\mathrm{o}}}+\frac{\varepsilon_{\delta \mathrm{M}_{\mathrm{o}}}}{2}\right] \\
\left.\frac{\mathrm{dn}}{\mathrm{dt}}\right|_{\mathrm{s}, \mathrm{M}_{\mathrm{o}}, \mathrm{n} \in \mathrm{A}} \in\left[\delta_{\mathrm{n}}-\frac{\varepsilon_{\delta \mathrm{n}}}{2} ; \delta_{\mathrm{n}}-\frac{\varepsilon_{\delta \mathrm{n}}}{2}\right]
\end{aligned}
$$

In defining of the majority of dynamic states for engine testing the most often recorded is the engine torque not the moment of resistance. In such a case the elementary description of the engine operation can be done through a combination of derivatives in time: engine control by the operator, engine torque and speed. The engine operation quantities that fulfill the conditions:

$$
\begin{gathered}
\mathrm{s} \in\left[\mathrm{s}_{\mathrm{i}}-\frac{\varepsilon_{\mathrm{s}}}{2} ; \mathrm{s}_{\mathrm{i}}+\frac{\varepsilon_{\mathrm{s}}}{2}\right] \\
\mathrm{M}_{\mathrm{e}} \in\left[\mathrm{M}_{\mathrm{ei}}-\frac{\varepsilon_{\mathrm{Me}}}{2} ; \mathrm{M}_{\mathrm{ei}}+\frac{\varepsilon_{\mathrm{Me}}}{2}\right] \\
\mathrm{n} \in\left[\mathrm{n}_{\mathrm{i}}-\frac{\varepsilon_{\mathrm{n}}}{2} ; \mathrm{n}_{\mathrm{i}}+\frac{\varepsilon_{\mathrm{n}}}{2}\right]
\end{gathered}
$$

form set B.

The derivatives of the engine operation quantities fulfill the conditions:

$$
\begin{aligned}
&\left.\frac{\mathrm{ds}}{\mathrm{dt}}\right|_{\mathrm{s}, \mathrm{M}_{\mathrm{e}}, \mathrm{n} \in \mathrm{B}} \in\left[\delta_{\mathrm{s}}-\frac{\varepsilon_{\mathrm{s}}}{2} ; \delta_{\mathrm{s}}+\frac{\varepsilon_{\mathrm{s}}}{2}\right] \\
&\left.\frac{\mathrm{dM}}{\mathrm{dt}}\right|_{\mathrm{s}, \mathrm{M}_{\mathrm{e}}, \mathrm{n} \in \mathrm{B}} \in\left[\delta_{\mathrm{M}_{\mathrm{e}}}-\frac{\varepsilon_{\mathrm{M}_{\mathrm{e}}}}{2} ; \delta_{\mathrm{M}_{\mathrm{e}}}+\frac{\varepsilon_{\mathrm{M}_{\mathrm{e}}}}{2}\right] \\
&\left.\frac{\mathrm{dn}}{\mathrm{dt}}\right|_{\mathrm{s}, \mathrm{M}_{\mathrm{e}}, \mathrm{n} \in \mathrm{B}} \in\left[\delta_{\mathrm{n}}-\frac{\varepsilon_{\mathrm{n}}}{2} ; \delta_{\mathrm{n}}+\frac{\varepsilon_{\mathrm{n}}}{2}\right]
\end{aligned}
$$

The elementary description of the engine operation is thus defined with the values of the processes that describe the engine operation and their derivatives in time at these points of the processes as well as the tolerances of the values of the processes and their derivatives in time.

The analysis of descriptions (16) - (21) and (22) - (27) when the conditions determining the derivatives in time are not taken into account i.e. (19) - (21) and (25) - (27), narrows the task to investigating the statistical conditions and states of engine operation.

The analysis of the descriptions (16) - (21) and (22) (27) when the conditions imposed on the processes are not taken into account i.e. (16) - (18) and (22) - (24) constitutes an investigation on the dynamic conditions ands states of engine operation averaged in the range of the analyzed values of the processes:

$$
\begin{gathered}
\mathrm{s} \in\left[\mathrm{S}_{\min } ; \mathrm{s}_{\max }\right] \\
\left.\mathrm{M}_{\mathrm{o}} \in \mathrm{M}_{\text {omin }} ; \mathrm{M}_{\text {omax }}\right] \\
\mathrm{n} \in\left[\mathrm{n}_{\text {min }} ; \mathrm{n}_{\max }\right]
\end{gathered}
$$

W takim wypadku elementarny opis pracy silnika może być opisany kombinacją pochodnych względem czasu: sterowania silnika przez operatora, momentu obrotowego i prędkości obrotowej. Wielkości pracy silnika spełniające warunki (22) - (24) tworzą zbiór B.

Pochodne wielkości pracy silnika spełniają warunki (25) - (27).

Elementarny opis pracy silnika jest zatem zdefiniowany wartościami procesów opisujących pracę silnika oraz ich pochodnych względem czasu w tychże punktach procesów oraz tolerancjami wartości procesów i pochodnych procesu względem czasu.

Rozpatrywanie opisów (16) - (21) oraz (22) - (27) bez uwzględniania warunków określających pochodne względem czasu, tzn. (19) - (21) i (25) - (27), sprowadza zadanie do badania statycznych warunków i stanów pracy silnika.

Z kolei rozpatrywanie opisów (16) - (21) oraz (22) - (27) bez uwzględniania warunków nałożonych na procesy, tzn. (16) - (18) i (22) - (24), stanowi badanie dynamicznych warunków i stanów pracy silnika, uśrednionych $\mathrm{w}$ zakresie rozpatrywanych wartości procesów (28) - (31).

Kolejnym znacznym uproszczeniem elementarnych opisów pracy silnika jest przyjęcie jako kwalifikacji do stanów jedynie znaku pochodnych: dodatniego lub ujemnego, w całym zakresie pracy silnika. Wówczas dla wielkości sterowania silnika przez operatora, momentu oporu i prędkości obrotowej są możliwe następujące elementarne stany pracy silnika: (32) - (37).

Z kolei dla wielkości sterowania silnika przez operatora, momentu obrotowego i prędkości obrotowej są możliwe następujące elementarne stany pracy silnika: (38) - (43).

Oczywiście opisy (28) - (33) i (34) - (39) można również rozpatrywać dla założonych zakresów wartości procesów. Można również tworzyć kombinacje warunków i stanów pracy silnika określonych zakresami wartości procesów, znakami pochodnych procesów względem czasu oraz pochodnych procesów względem czasu równych zeru $\mathrm{z}$ odpowiednio dobraną tolerancją (procesy stałe), np.: (44) dla (45).

Dla przyjętych warunków pracy i stanów silnika spalinowego ze względu na ich wartości wraz z zakresami ich tolerancji oraz ze względu na pochodną tych wielkości względem czasu wraz z zakresami ich tolerancji można badać wybrane właściwości silnika, np. wielkości charakteryzujące:

- właściwości energetyczne, m.in. moc użyteczną, czy średnie ciśnienie użyteczne,

- właściwości ekonomiczne silnika ze względu na zużycie paliwa (sprawność ogólną, jednostkowe zużycia paliwa, natężenie przepływu paliwa zużywanego przez silnik),

- emisję zanieczyszczeń (natężenie emisji, emisję jednostkową) i hałasu (poziom natężenia hałasu, poziom ciśnienia akustycznego). 


$$
M_{e} \in\left\lfloor M_{e m i n} ; M_{e \max }\right\rfloor
$$

Another significant simplification of the elementary descriptions of the engine operation is the adoption for qualification of only the sign of the derivatives: negative or positive in the whole range of engine operation. Then for the quantities of engine control by the operator, the moment of resistance and engine speed these engine states are possible:

$$
\begin{array}{llll}
\frac{\mathrm{ds}}{\mathrm{dt}}>0 ; & \frac{\mathrm{dM}_{\mathrm{o}}}{\mathrm{dt}}>0 & \Rightarrow & \frac{\mathrm{dn}}{\mathrm{dt}}>0 \\
\frac{\mathrm{ds}}{\mathrm{dt}}>0 ; & \frac{\mathrm{dM}_{\mathrm{o}}}{\mathrm{dt}}>0 & \Rightarrow & \frac{\mathrm{dn}}{\mathrm{dt}}<0 \\
\frac{\mathrm{ds}}{\mathrm{dt}}>0 ; & \frac{\mathrm{dM}_{\mathrm{o}}}{\mathrm{dt}}<0 & \Rightarrow & \frac{\mathrm{dn}}{\mathrm{dt}}>0 \\
\frac{\mathrm{ds}}{\mathrm{dt}}<0 ; & \frac{\mathrm{dM}_{\mathrm{o}}}{\mathrm{dt}}>0 & \Rightarrow & \frac{\mathrm{dn}}{\mathrm{dt}}<0 \\
\frac{\mathrm{ds}}{\mathrm{dt}}<0 ; & \frac{\mathrm{d} \mathrm{M}_{\mathrm{o}}}{\mathrm{dt}}<0 & \Rightarrow & \frac{\mathrm{dn}}{\mathrm{dt}}<0 \\
\frac{\mathrm{ds}}{\mathrm{dt}}<0 ; & \frac{\mathrm{dM}}{\mathrm{dt}}<0 & \Rightarrow & \frac{\mathrm{dn}}{\mathrm{dt}}>0
\end{array}
$$

For the values of the engine control by the operator, the moment of resistance and engine speed the following elementary engine states are possible:

$$
\begin{array}{llll}
\frac{\mathrm{ds}}{\mathrm{dt}}>0 ; & \frac{\mathrm{dM_{e }}}{\mathrm{dt}}>0 & \Rightarrow & \frac{\mathrm{dn}}{\mathrm{dt}}>0 \\
\frac{\mathrm{ds}}{\mathrm{dt}}>0 ; & \frac{\mathrm{dM}_{\mathrm{e}}}{\mathrm{dt}}>0 & \Rightarrow & \frac{\mathrm{dn}}{\mathrm{dt}}<0 \\
\frac{\mathrm{ds}}{\mathrm{dt}}>0 ; & \frac{\mathrm{dM}_{\mathrm{e}}}{\mathrm{dt}}<0 & \Rightarrow & \frac{\mathrm{dn}}{\mathrm{dt}}>0 \\
\frac{\mathrm{ds}}{\mathrm{dt}}<0 ; & \frac{\mathrm{dM}}{\mathrm{dt}}>0 & \Rightarrow & \frac{\mathrm{dn}}{\mathrm{dt}}<0 \\
\frac{\mathrm{ds}}{\mathrm{dt}}<0 ; & \frac{\mathrm{dM}}{\mathrm{dt}}<0 & \Rightarrow & \frac{\mathrm{dn}}{\mathrm{dt}}<0 \\
\frac{\mathrm{ds}}{\mathrm{dt}}<0 ; & \frac{\mathrm{dM}}{\mathrm{dt}}<0 & \Rightarrow & \frac{\mathrm{dn}}{\mathrm{dt}}>0
\end{array}
$$

Of course, the descriptions (28) - (33) and (34) - (39) can be analyzed for the assumed ranges of values of the processes. We can also create combinations of conditions and states of engine operation determined by the ranges of values of the processes, signs of the derivatives in time and the derivatives of the processes in time that equal zero with an appropriately selected tolerance (steady processes) e.g.:
W podsumowaniu rozważań na temat badania właściwości silników spalinowych w stanach dynamicznych należy stwierdzić, że w ogólności nie istnieją takie właściwości jako niezależne od stanów silników. Istnieje - w związku z tym - konieczność ograniczania ogólności zadań badania silników spalinowych, pracujących w warunkach dynamicznych, w postaci nakładania na badany układ pewnych więzów jako przyjętych procedur badawczych, np. pewnej klasy procesów stanowiących warunki pracy, lub przyjętego sposobu przetwarzania wyników badań, m.in. uśredniania w zakresie wartości procesów.

Jako przykład badań emisji zanieczyszczeń przedstawiono analizę wyników badań silnika Detroit Diesel Series 50, spełniającego wymagania na poziomie Euro III. Badania przeprowadzono w warunkach testu dynamicznego HDDTT (Heavy Duty Diesel Transient Test). Na rysunku 3 przedstawiono przebiegi prędkości obrotowej i momentu obrotowego silnika.
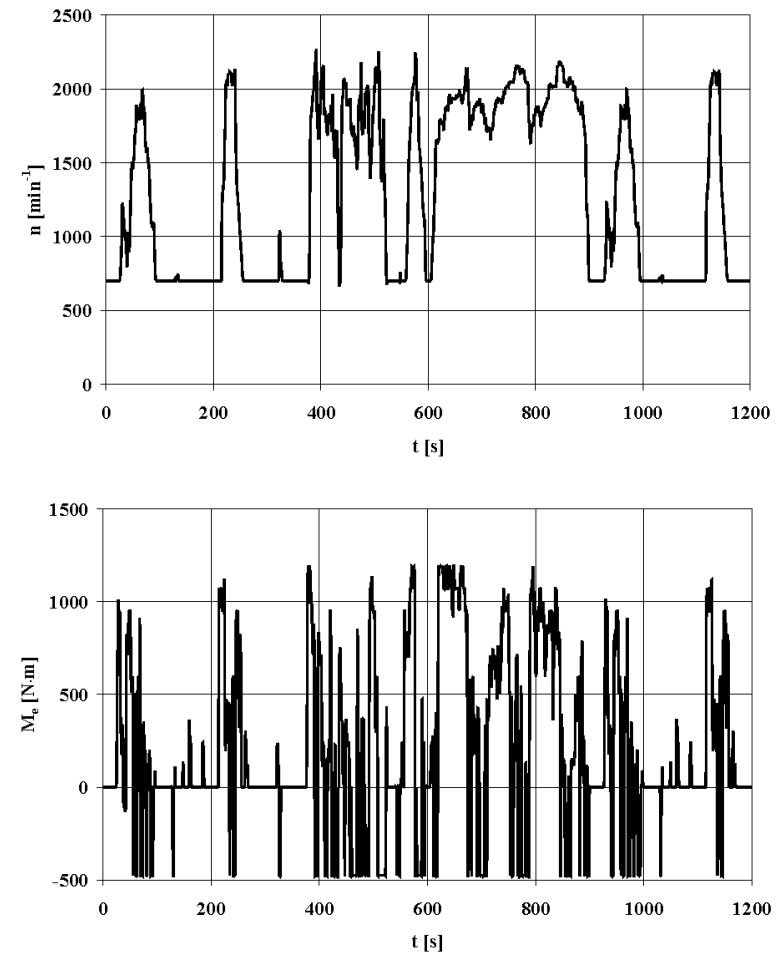

Fig. 3. The courses of the engine speed $n$ and torque $M_{e}$ of the engine in the HDDTT test

Rys. 3. Przebiegi prędkości obrotowej n i momentu obrotowego $M$ silnika w teście HDDTT

Na rysunku 4 przedstawiono przebiegi natężenia emisji zanieczyszczeń.

Przeprowadzono badania dla stanów odpowiadających: - testowi HDDTT,

- zwiększającej się prędkości obrotowej

$$
\frac{\mathrm{dn}}{\mathrm{dt}}>0
$$




$$
\frac{\mathrm{ds}}{\mathrm{dt}}>0 ; \quad \frac{\mathrm{dM}}{\mathrm{dt}} \in\left[\delta_{\mathrm{M}_{\mathrm{e}}}-\frac{\varepsilon_{\delta \mathrm{M}_{\mathrm{e}}}}{2} ; \delta_{\mathrm{M}_{\mathrm{e}}}+\frac{\varepsilon_{\delta \mathrm{M}_{\mathrm{e}}}}{2}\right]
$$

for

$$
\left.\mathrm{s} \in\left[\mathrm{E}_{\min } ; \mathrm{s}_{\max }\right] \quad \mathrm{n} \in\left[\mathrm{n}_{\text {min }} ; \mathrm{n}_{\max }\right] \quad \mathrm{M}_{\mathrm{e}} \in \mathbb{M}_{\mathrm{emin}} ; \mathrm{M}_{\mathrm{emax}}\right\rfloor
$$

For the assumed conditions of operation and states of engine operation in terms of the derivative of these quantities in time together with their tolerance ranges we can investigate selected engine properties such as the quantities that characterize:

- energy related properties such as power output, torque, engine speed or mean effective pressure,

- economic properties in terms of fuel consumption such as, general efficiency, fuel flow rate, specific fuel consumption,

- exhaust emissions (emission rate, unit emission) and noise emissions (noise level, acoustic pressure level).

Concluding the discussion on the investigations of the properties of combustion engines in dynamic states we should note that in general there are no such properties as properties independent from the engine states. Hence, there is a necessity to limit the generality of tasks of testing of combustion engines that operate in dynamic states by imposing certain constraints as adopted testing procedures - a class of processes that constitute the operating conditions or an adopted manner of processing of the test results i.a. averaging in the range of the values of the processes.

As an example of the exhaust emission tests an analysis has been presented of the Detroit Diesel engine Series 50 that conforms to the Euro III standard. The tests were performed in the dynamic conditions of HDDTT (Heavy Duty Diesel Transient Test). In figure 3 the courses of engine speed and engine torque have been presented.

Figure 4 presents the courses of the exhaust emission rate.

The tests were performed for the states that correspond to:

- HDDTT test,

- Increasing engine speed

$$
\frac{\mathrm{dn}}{\mathrm{dt}}>0,
$$

- Decreasing engine speed

$$
\frac{\mathrm{dn}}{\mathrm{dt}}<0,
$$

- Variable engine speed

$$
\frac{\mathrm{dn}}{\mathrm{dt}}<0 \quad \text { or } \quad \frac{\mathrm{dn}}{\mathrm{dt}}>0 ;
$$

and an assumption was made that these conditions equal the conditions of engine speed above idle $n_{b j}$

$$
\mathrm{n}>\mathrm{n}_{\mathrm{bj}}
$$
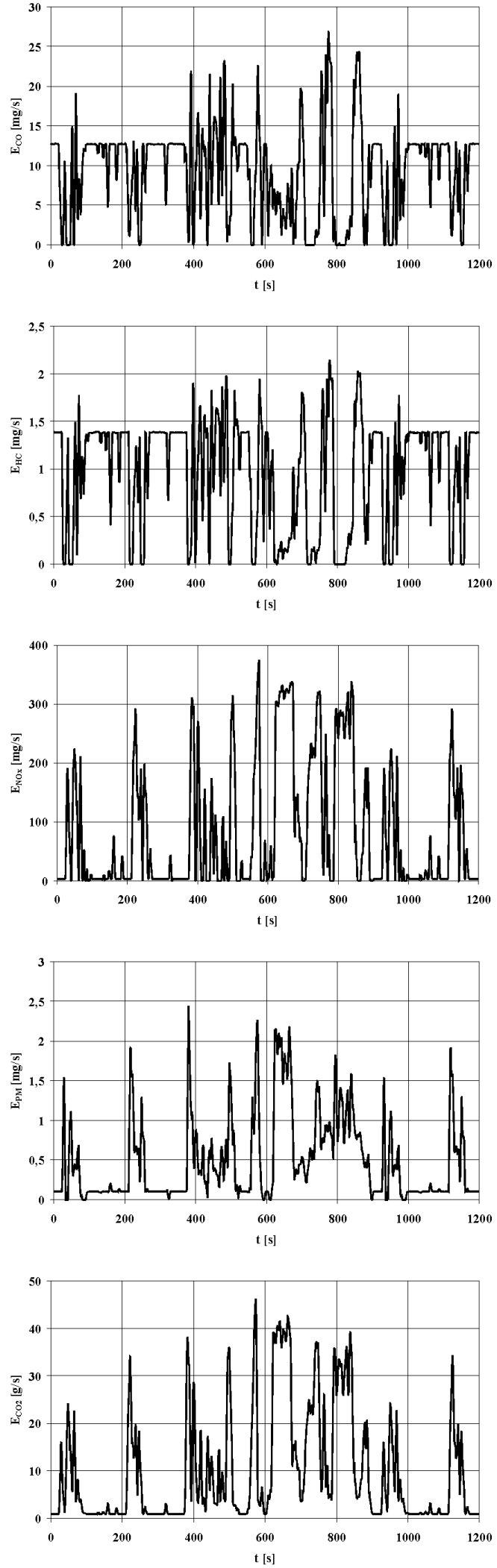

Fig. 4. The courses of the emission of: carbon monoxide $\mathrm{E}_{\mathrm{CO}}$, hydrocarbons $\mathrm{E}_{\mathrm{HC}}$, nitric oxides $\mathrm{E}_{\mathrm{NOx}}$, particulate matter $\mathrm{E}_{\mathrm{PM}}$ and carbon dioxide $\mathrm{E}_{\mathrm{CO} 2}$ in the HDDTT test

Rys. 4. Przebiegi natężenia emisji: tlenku węgla $E_{C O}$, węglowodorów $E_{H C}$ tlenków azotu $E_{\mathrm{NOx}}$, czastek statych $E_{P M}$ i dwutlenku węgla $E_{\mathrm{CO} 2}$ w teście HDDTT 
For the assumed dynamic states average exhaust emission rate was determined - Fig. 5 .

Even at such a schematic division into the dynamic engine states that include only the properties of the process of the engine speed we can clearly see differences in the average exhaust emission rate. A strong influence of the engine acceleration on the exhaust emission of particulate matter and nitric oxides as well as carbon dioxide is observed. A reduction in the engine speed facilitates the growth of the emission of carbon monoxide and hydrocarbons. The distinguished dynamic states (within each of them) are related to various dynamic states of the engine torque thus we should expect that for more accurately formulated dynamic states the engine properties would be much different.
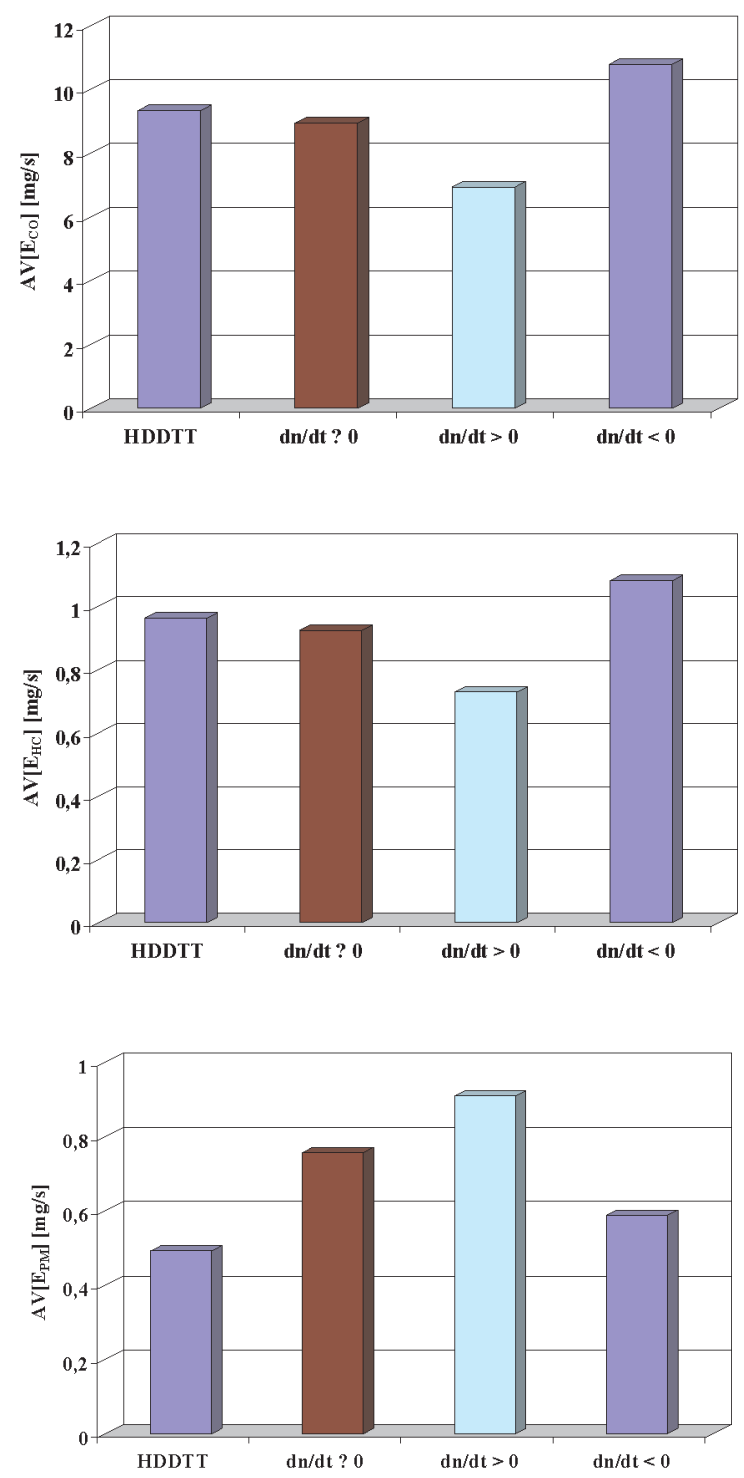

- zmniejszającej się prędkości obrotowej

$$
\frac{\mathrm{dn}}{\mathrm{dt}}<0,
$$

- zmiennej prędkości obrotowej

$$
\frac{\mathrm{dn}}{\mathrm{dt}}<0 \quad \text { lub } \quad \frac{\mathrm{dn}}{\mathrm{dt}}>0 ;
$$

przyjęto założenie, że warunek ten jest tożsamy z warunkiem prędkości obrotowej większej od prędkości obrotowej biegu jałowego $n_{b j}$

$$
\mathrm{n}>\mathrm{n}_{\mathrm{bj}}
$$

Dla przyjętych stanów dynamicznych wyznaczono średnie natężenia emisji zanieczyszczeń - rysunek 5 .

Nawet przy tak schematycznym podziale na stany dynamiczne silnika, uwzględniającym jedynie właściwości procesu prędkości obrotowej, wyraźnie są widoczne różnice $\mathrm{w}$ średnich natężeniach emisji zanieczyszczeń. Jest znamienny silny wpływ przyspieszania silnika na zwiększanie się natężenia emisji cząstek stałych i tlenków azotu, a także dwutlenku węgla. Zmniejszanie prędkości obrotowej sprzyja zwiększaniu natężenia emisji tlenku węgla i węglowodorów. Wyróżnione stany dynamiczne dotyczą - w ramach każdego z nich - różnych stanów dynamicznych momentu obrotowego, w związku z czym należy oczekiwać, że dla bardziej szczegółowo sformułowanych stanów dynamicznych właściwości silnika będą się różnić znacznie.
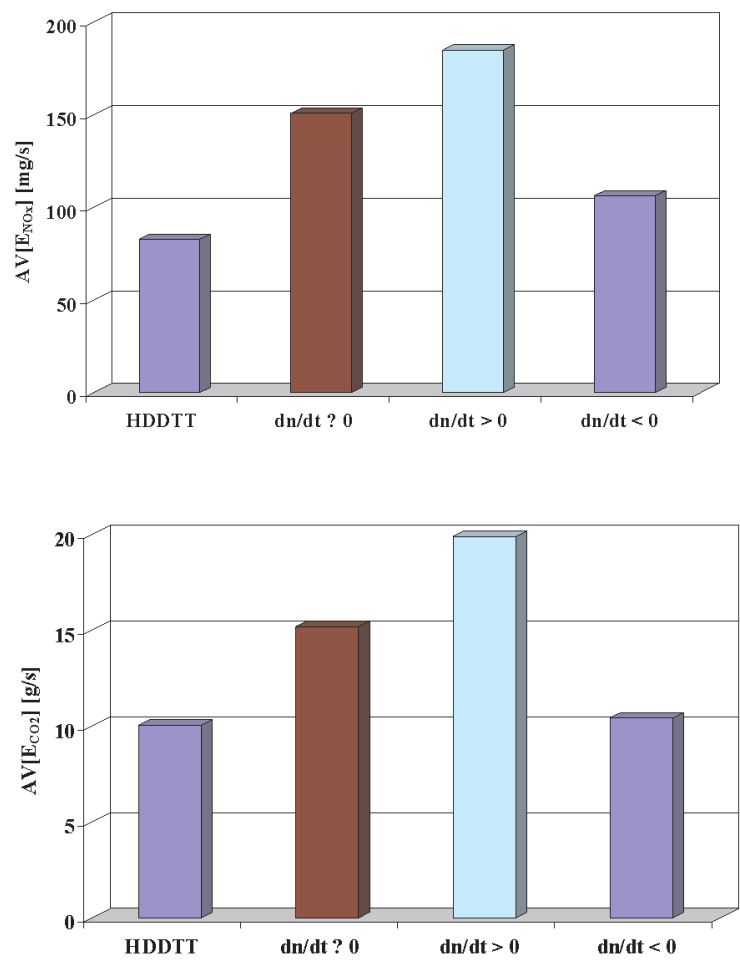

Fig. 5. Average exhaust emission rate of carbon monoxide $\mathrm{AV}\left[\mathrm{E}_{\mathrm{CO}}\right]$, hydrocarbons $\mathrm{AV}\left[\mathrm{E}_{\mathrm{HC}}\right]$, nitric oxides $\mathrm{AV}\left[\mathrm{E}_{\mathrm{NOx}}\right]$, particulate matter $\mathrm{AV}\left[\mathrm{E}_{\mathrm{PM}}\right]$ and carbon dioxide $\mathrm{AV}\left[\mathrm{E}_{\mathrm{CO} 2}\right]$ in the tested dynamic states

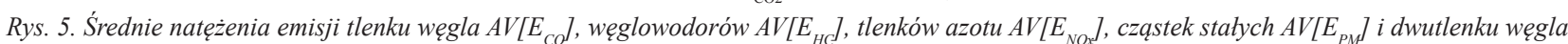
$A V\left[E_{\mathrm{CO} 2}\right]$ w badanych stanach dynamicznych 


\section{Concluding remarks}

The dynamics of combustion engines, even though most of them operate in dynamic states, is not a field of science that has established standards. This is a result of many years of practicing engine investigations in static states, which is substantiated by the basic insight investigations into the processes that occur in the engine and also by the multidimensional adjustment investigations. At the same time the knowledge is quite common of the significant differences between the engines in static and dynamic states. Hence, there is a growing need to develop engine investigations in dynamic states.

This work constitutes an attempt to put in order matters related to the engine investigations in dynamic states. The proposed formalism enables a rational systemization of issues that occur in this type of investigations.

The examples presented in the paper indicate that the proposed approach to the issue allows an efficient exploration of the properties of the engines operating in dynamic states.

The continuation of the here discussed task should be oriented towards an attempt to formalize the dynamic states so that the systematics is well justified in terms of practical application and to enable empirical investigations.

Paper reviewed/Artykut recenzowany

\section{Uwagi końcowe}

Dynamika silników spalinowych, mimo że większość silników pracuje głównie w warunkach dynamicznych, nie należy do nauk o ugruntowanych standardach. Wynika to m.in. z wieloletniej praktyki badania właściwości silników spalinowych w warunkach statycznych, co znajduje uzasadnienie w prowadzeniu podstawowych wnikliwych badań procesów zachodzących w silnikach, a także wielowymiarowych badań regulacyjnych. Jednocześnie powszechna jest wiedza o znacznych różnicach we właściwościach silników spalinowych, znajdujących się w stanach statycznych i dynamicznych. W związku z tym istnieje coraz bardziej istotna potrzeba rozwijania badań silników spalinowych w warunkach dynamicznych.

Niniejsza praca stanowi próbę wstępnego uporządkowania spraw, związanych z badaniami silników spalinowych w warunkach dynamicznych. Zaproponowany formalizm umożliwia racjonalne usystematyzowanie problemów występujących w tego rodzaju badaniach.

Przytoczone w pracy przykłady wskazują, że zaproponowany sposób podejścia do problemu umożliwia skuteczne poznanie właściwości silników pracujących w warunkach dynamicznych.

Kontynuacja podjętego zadania powinna dotyczyć przede wszystkim próby sformalizowania na tyle szczegółowych stanów dynamicznych, aby zaproponowana systematyka była uzasadniona względami praktycznymi, a także by było możliwe skuteczne wykonanie badań empirycznych.

\section{Bibliography/Literatura}

[1] Arregle J., Bermudez V., Serrano J. R., Fuentes E.: Procedure for engine transient cycle emissions testing in real time. Experimental Thermal And Fluid Science. 2006. Volume 30, no5. 485-496.

[2] Banach S.: Teoria operacyj. Tom I. Operacje linjowe. Wydawnictwo Kasy im. Mianowskiego Instytutu Popierania Nauki. Warszawa 1931.

[3] Bendat J. S., Piersol A. G.: Metody analizy i pomiaru sygnałów losowych. PWN. Warszawa 1976.

[4] Bermúdez V., Luján J. M., Serrano J. R., Pla B.: Transient particle emission measurement with optical techniques. Measurement Science and Technology 2008 - 19065404.

[5] Chłopek Z.: Analiza emisji zanieczyszczeń z trakcyjnego silnika spalinowego. Mechanics and Mechanical Engineering 1/2005. Volume 9. Wydawnictwo Politechniki Łódzkiej. Łódź 2005. 43-68.

[6] Chłopek Z.: Metody badań właściwości silników spalinowych w warunkach przypadkowych modelujących użytkowanie. Archiwum Motoryzacji 4/2001. 187-210.

[7] Chłopek Z.: Modelowanie procesów emisji spalin w warunkach eksploatacji trakcyjnej silników spalinowych. Prace Naukowe. Seria „Mechanika” z. 173. Oficyna Wydawnicza Politechniki Warszawskiej. Warszawa 1999.

[8] Chłopek Z., Laskowski P.: Charakterystyki emisji zanieczyszczeń wyznaczane metodą Monte Carlo. Eksploatacja i Niezawodność - Maintenance and Reliability Nr 1 (21)/2004. 3-13.
[9] Chłopek Z., Pawlicki M., Sypowicz R.: Analiza dynamiczna emisji zanieczyszczeń z silnika o zapłonie samoczynnym. Zeszyty Naukowe Instytutu Pojazdów Politechniki Warszawskiej 3(58)/2005. 95-102.

[10] Kniaziewicz T., Piaseczny L., Zadrąg R.: Toksyczność spalin okrętowego silnika spalinowego podczas jego rozruchu. Zeszyty Naukowe Akademii Marynarki Wojennej 1999 nr 2. 51-63.

[11] Merkisz J.: Emisja cząstek stałych przez silniki spalinowe o zapłonie samoczynnym. Wydawnictwo Politechniki Poznańskiej. Poznań 1997.

[12] Sobczyk K.: Metody dynamiki statystycznej. PWN. Warszawa 1973.

[13] Wang J., Storey J., Domingo N., Huff S., Thomas J., West B.: Studies of diesel engine particle emissions during transient operations using an engine exhaust particle sizer. Aerosol Science and Technology

Mr. Zdzisław Chłopek, DSc., DEng. - Professor in the Faculty Automotive and Construction Machinery Engineering at Warsaw University of Technology.

Dr hab. inż. Zdzisław Chtopek - profesor na Wydziale Samochodów i Maszyn Roboczych Politechniki Warszawskiej.

e-mail:moriarty@o2.pl 